\title{
Engaging the Press in the Rethinking of Nigeria's Foreign Policy: Problems and Prospects
}

\section{Nworgu KO ${ }^{1 *}$, Obiajulu Emejulu ${ }^{2}$ and Chukwudi $\mathrm{OB}^{3}$}

${ }^{1}$ Department of Mass Communication, Imo State University, Owerri, Nigeria

${ }^{2}$ National Institute for Nigerian Languages (NINLAN), Aba, Abia State, Nigeria

${ }^{3}$ School of General Studies, Michael Okpara University of Agriculture, Umudike, Abia State, Nigeria

\begin{abstract}
Foreign policy is a product of complex interest within a bureaucratic set-up made up of political executives, legislatures, political oppositions, interest groups and citizens represented in public opinion of the attentive public. The press acts either as the voice, reflector, or the organ of public opinion or it may serve as the controller, regulator or even creator of public opinion for most national or international issues. The major issues in Nigerian foreign policy include strengthening of African Solidarity through the continental and regional organizations and institutions like A.U. and ECOWAS; participating actively in support for international organizations such as the United Nations; Supporting the right of people to self determination and freedom from colonial and foreign subjugation and for all liberation movements in their legitimate struggle for national independence; Supporting the right of people to self determination and freedom from colonial and foreign subjugation and for all liberation movements in their legitimate struggle for national independence and supporting all efforts to dismantle any form of colonialism in Africa and all of forms social bigotry and prejudice, Nigeria's relationship with her immediate neighbours. This has to do with the desire and effort of the nation at maintaining a good relationship with our immediate neighbours. International relations issues affecting nations are better appreciated when information about them are made available to all concerned parties including the press. This paper among other things recommend that Should utilize the opportunities provide by globalization and new information and communication technologies to create linkages and varied information sources for better reportage of the country's foreign policy issues.
\end{abstract}

\section{Keywords: Nigeria; Press; Foreign Policy; Media}

\section{Introduction}

Current themes in the study of international relations and foreign policy appear to be increasingly interdisciplinary [1]. "Much of international relations teaching and research is still weighted heavily in favour of some more established disciplines, notably history, political science, law and economics and to an increasing extent, sociology, social psychology and cultural anthropology". Obviously, the areas of interest to scholars in international relations are broad but specifically covering such issues as: power, international institutions and organisations, international systems, integration and the community approach [2], conflict and conflict management and resolution Ideologies; nationalism, imperialism and colonialism, national interest, decision making and policy formulation; political and international behavior [3], alliance systems and alliance politics; arms control and disarmament; demography studies and economic factors[4].

Ironically, the world is becoming increasingly interdependent. The historic prevalence of the notions of local, national and regional views clashing with global consensus; and the dominance of privileged and powerful few in the gradual evolution of international system have not only shaped the operations and conduct of states system; they also have essentially determined the general direction and conception of the study of international relations. Therefore, it is essential to study how relationships are built in international scenes. Some studies have been carried out in Nigeria as regards the press coverage of national and international issues. The findings of these studies show that Nigerian press has contributed greatly to the development of the country. Apart from studies about the press in the last two decades in Nigeria, there have been renewed interests in the contributions of the press on a wide variety of issues that affect national development, not only in Nigeria but all over the world. For instance, Atwood and Major studied colonial ties and news coverage of third world. Author in a study sought to find out the image of Africa as reflected by the elite American press [3]. Author studied Nigeria's foreign policy over the years of independence. Also, some media scholars have studied the nation's foreign policy under different regimes and such studies have shown the extent the press has protected national interests, especially, in contributing to making Nigeria a better place for the citizens and foreigners alike. Also, the role of the press in Nigeria's support for the liberation struggles in Africa is well documented [5].

\section{Meaning and Scope of Nigerian's Foreign Policy}

Foreign policy making is not the product of the president alone. Rather, it is a product of complex interest within a bureaucratic setup made up of political executives, legislatures, political oppositions, interest groups and citizens represented in public opinion of the attentive public. The press acts either as the voice, reflector, or the organ of public opinion or it may serve as the controller, regulator or even creator of public opinion for most national or international issues [6]. Based on this role, the press has championed opinions and shaped public perception of several national and international issues. Media representation plays a significant role in helping us understand the world around us (Davis \& Gandy Jr). However, in most countries of

${ }^{*}$ Corresponding author: Nworgu KO, Department of Mass Communication, Imo State University, Owerri, Nigeria, Tel: +2348062303484; E-mail: konworgu@yahoo.com

Received January 30, 2018; Accepted August 16, 2018; Published August 23, 2018

Citation: Nworgu KO, Emejulu O, Chukwudi OBI (2018) Engaging the Press in the Rethinking of Nigeria's Foreign Policy: Problems and Prospects. J Mass Communicat Journalism 8: 385. doi: 10.4172/2165-7912.1000385

Copyright: (c) 2018 Nworgu KO, et al. This is an open-access article distributed under the terms of the Creative Commons Attribution License, which permits unrestricted use, distribution, and reproduction in any medium, provided the original author and source are credited. 
the world, including the supposedly developed countries, information is ruthlessly suppressed by government, while in some countries; the press is out rightly censored. In Nigeria, the various dictatorial military regimes have affected the way information is handled by either the press or the citizens. The press and the government often clash because of the traditional role of the press as a watchdog. Most times the press tries to uncover and publicise that which the government wants to hide. While the journalist functions as the gatekeeper of information to the public, the foreign policy decision makers usually somehow rely on the press for information about foreign affairs. The press also usually depends on government for information to sell the papers. Balancing these vested interests in foreign policy reporting is the focus of this paper. The study, therefore, examined the role of the press in Nigeria's foreign policy, in line with the nature and dynamics of the nation's foreign policy.

\section{Nigeria's Foreign Policy Thrust and the Need for Review}

Foreign policy is the centre range of activities a nation pursues in its day-to-day relations with other nations in order to achieve its national interest as defined by its leaders [7]. "The dynamics of the environment for foreign policy has also altered significantly with emergence of new frameworks, new alliances and structures which now introduce new elements in terms of alliance \& politics which are elevating multilateralism to a new level thus increasing pressure on actors at the international stage". "Nigeria's foreign policy objectives clearly highlight the needs, norms and values of Nigeria as the basis of her association and co-operation with other countries of the world". Therefore, Nigerian foreign policy will include but not limited to the following:

The strengthening of African Solidarity through the continental and regional organizations and institutions like A.U. and ECOWAS;

The promoting of peace and stability on the African continent and security in west African sub-region, as well as, commitment to principles of respect for the provision of the AU charter, especially, those relating to the inviolability of international frontiers, sovereign equality and territorial integrity of all countries and peaceful accommodation and settlement of all disputes, without foreign interference;

Participating actively in support for international organizations such as the United Nations;

Supporting the right of people to self determination and freedom from colonial and foreign subjugation and for all liberation movements in their legitimate struggle for national independence;

Finally, supporting all efforts to dismantle any form of colonialism in Africa and all of forms social bigotry and prejudice [8].

\section{Re-thinking Nigeria's Foreign Policy}

Following the successful enthronement of democracy and the majority rule in South Africa, the independence of all African nations, the feeling is that there is the need for the country to redefine her foreign policy objectives, so as to tackle the continent's multi faceted problems which range from corruption, dictatorship, ethnic conflicts, to neo colonialism and imperialism as witnessed in the fresh scramble for Africa by the West as exemplified in free trade and globalization [9]. But the problem is that most times, the developing nations like Nigeria, are involved in ad-hoc planning and execution of national objectives, in form of foreign policy, whilst, the developed countries are involved in long range planning of foreign policy objectives [10]. Hence, foreign policy restructuring should be a critical examination of decision making structures and processes, at national level. This will lead to more organized actions, inactions and reactions by the nation to international issues and events and a critical examination of how they affect Nigeria and other countries.

There are a number of approaches to foreign policy analysis as observed by Bruck and Sapin in Asobie. The two basic approaches to foreign policy analysis are: the mechanistic approach which tries to focus on the organizational structure of the departments involved in foreign policy formulation, including the Foreign Ministry of a nation. Here, the emphasis is on how these institutions work and how foreign policy decisions are arrived at by those responsible for the nation's foreign policy formulation and execution. However, Asobie feels that this approach cannot be applied in analyzing the foreign policy of developing nations, since the roles of individual policy makers are not properly defined and there is lack of adequate information. In his words: "It would seem that the most underdeveloped countries hold a view of foreign policy which assumed that effectiveness in foreign policy formulation and implementation is simply a function of both the quality of the diplomatic service personnel and the organizational structure of the Foreign Ministry".

To this end, Asobie feels that in developing nations, power and influence as means of achieving foreign policy goals are not often recognized. Hence, foreign policy strategies in developing countries are never consciously and systematically worked out. This is against what is obtainable in developed countries where foreign policy consists of fairly rational goals, formulated in the light of realistically assessed means for their achievement. Such goals are embodied in "national interest with a lot of means of achieving them which include: threats and rewards and these enable the developed nations to exercise control and influence on national issues". To this end, the developed countries try to divide their foreign policy objectives into both long and short term planning for formulation and implementation. One will agree with Asobie's view that developing nations' foreign policy goals are not strategically formulated. For instance, the reaction of Nigerian government to the deportation of some Nigerians from South Africa over their yellow fever vaccination cards suspected to be fake and the Nigerian government's retaliatory diplomacy which led to the deportation of 131 illegal aliens (from South Africa), is the most uncoordinated diplomatic actions of all Nigerian foreign policy initiatives (The Nations, Saturday, $17^{\text {th }}$ March, 2012). What that meant is that we never had any policy of checking illegal immigrants in Nigeria in the first place.

\section{Problems of Rethinking Nigeria's Foreign Policy}

In attempting to understand Nigeria's foreign policies, author tried to analyze them based on the following assumptions, which he said are usually erroneous:

That the foreign policy is what the Foreign Ministry does and therefore the roles of other ministries, like Finance, Trade and Industries, Mines and Powers, Petroleum, Economic Development, Education, etc are outside the scope of such inquiry;

That the foreign policy system of a developing country like Nigeria is highly centralized with chief executive, the President, the Head of State or Government, assisted, sometimes, by his Foreign Minister, playing the role not just of the chief decision maker, but, infact, often, of the only decision maker;

That a clear distinction could be drawn between domestic issues and policies and external stimuli in determining the direction of the foreign policies of developing country like Nigeria. 
The above observations are true to some extent but these thinking and approaches have limited gains in terms broad perspectives on the nation's foreign policy. It has limited the benefits the nation could derive from her support of African countries liberation and indeed in world politics.

To this effect, describes foreign policy as "image building". He sees image building as an essential element in the strategy of foreign policy. Nnoli states that in order to be successful in external relations, the image of the country which foreign policy makers wish to create, must conform to the image of it, which other countries have. The foreign policy of any country is always the reflection of the philosophies of that country. Hence, the pursuit of foreign policy is a mark of independence, as well as an ideological foundation of a nation. Most times, foreign policy issues can be pursued for both positive and negative ends. The positive ends border on what the country can gain in terms, of national security, economic prosperity and political stability. The negative end can be said to border on preventing other countries from harming or undermining a country's national interest. Sometimes, a nation can go to the extreme of waging a war to protect such interest.

From the above explanations, it can be seen that foreign policy is a dynamic process and also a product of both internal and external environment. Therefore, it should be reviewed from time to time. Many analysts have suggested that we can understand a nation's foreign policy by taking a look at its domestic environment or the international systems. The major issues in Nigerian foreign policy are those that border on: Nigeria's relationship with her immediate neighbours. This has to do with the desire and effort of the nation at maintaining a good relationship with our immediate neighbours: "It was seen not only, to be consistent with our avowed principle of promoting good neighbourliness and African solidarity, but also as a real insurance for guaranteeing security and stability at home. The country has always been in close contact with her neighbour in West Africa and indeed the whole of the African continent. In the bid to maintain close political and economic ties with fellow African nations, Nigeria substantially contributes to the effective running of the affairs of the African Union (AU), (which are concerned with African political and social unity), and ECOWAS which is concerned with regional economic integration of West African states. But the question there is: has Nigeria benefitted maximally from her financial contributions to these regional organizations?

\section{Engaging the Press in Foreign Policy Making}

The role of the press in the process of foreign policy making varies from one country to another. Also, the problems confronting the press in carrying out such role vary from country to country. Such problems as the uncooperative posture of the government have been identified. Also, there is the socio-economic outlook of a nation which may prevent the press from performing effectively in foreign policy issues.

The discussions of the role of the press in foreign policy always adopt a two-level methodological approach predicated on examining what must interest has in particular from policy issues and by looking at the extent to which the press has been supportive or otherwise about foreign policy issues within a particular time frame. This may take the form of content analysis in order to underscore their positions.

As MacBride have noted, the press been described as the fourth estate because, full and accurate information on matters of public interest is the means by which governments institutions, organizations and public function. Nevertheless, those in authority often tend to prevent and hid that which is not convenient to them or likely to arouse public opinion against them.

Going by the statements by various Nigerian government officials, the press is to be seen as a partners or collaborators in foreign policy. As Opubor argues: it has also usually been assumed that the interest of the nation is what government actions are for. In some cases, the role of the press in foreign policy may be hampered by media, ideology, ownership structure and editorial policy(s). for instance, in Nigeria, the dominant pattern of ownership of print media is private ownership, while government ownership dominates the electronic media. It is a known fact the ownership can affect foreign policy coverage through either news slanting or outright blackout. Usually government owned press support government policies without questioning their rationale.

As Waisbord notes: to enhance the quality of press performance, it is necessary to promote media pluralism, increase accountability of government decision affecting the press and strengthen coverage of civic issues and opinions.

\section{Prospects of Nigeria's Foreign Policy}

Foreign policy "simply means the general guidelines and course of action which may be embodied in legal documents, statues, verbal pronouncement and/or consistent behavior pattern, adopted by a person(s), organizations, and government etc, especially by those empowered or in a position to do so". He further defines Nigeria's foreign policy as Nigeria's government or its authorized official guidelines for action or consistent behavioural pattern towards events, issues and processes which could be earthquakes, a new international economic order, trade with other countries, or threat to the national security. Ogbani's assertion that there is no sharp destination between domestic and foreign policy is true. However, in as much as the domestic policies of a nation can reflect in her foreign policy, there is always the need to differentiate between the two environments. While all foreign policies can affect one nation or the other, the effect of some domestic policies may be restricted mostly within the internal environment and publics. Furthermore, as Idang opines: "There is no policy that one can easily be said be Nigeria's foreign policy. The foreign policy of every nation state is virtually the same even though its integration, strategies and mechanisms of implementation may be different". The above observations are faulty because the writer failed to understand that Nigeria for not having a definite foreign policy is a policy strategy itself. For that reason Nigeria has a foreign policy which is rather centered on the unity, integration and co-operation of African State. Hence, Africa is the centre piece of Nigeria's foreign policy.

Also, one disagrees with Idang's assertion that the foreign policy of every nation is virtually the same, because no two nations can have the same national ideology, political or historical background. Therefore, nations are different in their foreign policy objectives. For instance, the advanced countries may be interested in neo-colonialism and imperialism (both political and cultural) while developing nations are still battling with hunger and disease control and these may shape their foreign policy issues. Again, some countries may decide to take sides in world politics as witnessed during the cold era and recently the gulf wars, but most African nations and indeed, most third world countries have non-aligned disposition, preferring economic aid or grants from whoever cares to give out one. Mostly, the foreign policy thrust of developing countries like Nigeria defer from those of the developed nations, while the developed nations are dominating the world economic, political and social system, the developing nations are clamouring for new world information and economic order. These and 
many more issues form the basis for different foreign policy programmes by different nations whether developed or underdeveloped Obiukwu, sees foreign policy as a country's response to the external stimuli and this is usually meant to achieve some definite national objectives. This definition does not take into account the fact that foreign policy is not all about counter action but also about acting first or stimulating others first. A nation's foreign policy can be adjudged as being vibrant when it can take actions first on national and international issues, without waiting for external prompting and stimuli or reacting promptly when stimulated by external events or issues.

The truth remains that Nigeria foreign policy should be reviewed in line with the realities of the time. Time has come for pragmatic and mutual benefits driven foreign policy initiatives. This is the way to go in the face of the complaints that Nigerian citizens do not benefit from Nigeria's foreign policies, especially, northern Sub-African region and African continent, where Nigerians have continued to be treated like common criminals, even when there are evidence of their legitimate means of livelihood and genuine travelling documents.

The press is expected to support such rethinking in Nigeria's foreign policy initiatives. Whenever, the media support foreign policy posture of government, the government is rest assured that it is on right path and such policy posture has the peoples' backing. Therefore, the post modern information and communication at the international level is characterized heavily by information technology which has made Marshal McLuhan's idea of a global village a reality. To this effect, critical communication researchers and experts have argued that the press must meet these challenges of globalization of foreign policy with resolute consistency.

\section{Conclusion}

International relations issues affecting nations are better appreciated when information about them are made available to all concerned parties including the press. Ironically, studies in international relations and literature in foreign policy have constantly ignored the relevance of communication in foreign policy initiation and implementation. Therefore, with or without being coopted, Nigeria is expected to play a lot roles especially rethinking of the nation's foreign policies in line with realities of the time and for the benefit of Nigerian citizens and government.

\section{Recommendations}

We recommend that the press:

Should go beyond mere straight news reporting about foreign policy issues to provide critical analysis and complying explanations on some foreign policy initiatives of Nigerian government;

Should constantly interest with foreign policy experts in the ministry of external affairs to understand underlying factors behind certain foreign policy initiatives;

Should utilize the opportunities provide by globalization and new information and communication technologies to create linkages and varied information sources for better reportage of the country's foreign policy issues.

\section{References}

1. Agwu FA (2010) Reciprocity and its implicatiosn international relations. Reciprocity in International Relations.

2. Akinyemi B (2007) Nigeria: The Blackman's Burden.

3. Atwood LE, Major AM (2000) Colonial Ties and News Coverage of the Third World. Trends in Global Communication and Research Paradigms.

4. Akinnyemi AB (1974) Foreign Policy and Federalism: The Nigerian Experience.

5. Idang GJ (1973) Nigeria: Internal Politics and Foreign Policy 1960-1966. Ibadan University Press.

6. Jibrin A (2004) Obasanjo and the New face of Nigeria's Foreign Policy. Kaduna: Press and Publishers.

7. Nwuneli O, Udoh E (1982) International news coverage in Nigerian Newspapers Gazette 29: 31-40.

8. Obiukwu C (2001) Foundation of Contemporary. International Relation.

9. Rourke JT (1997) International Politics on the World Stage.

10. Uche LU, Ngumoha UN (2000) Anglo-Nigerian Press coverage of a Diplomatic Scandal. 